\title{
BACK TO NATURE: KEMAJUAN ATAU KEMUNDURAN
}

\author{
Indah Karina Yulina
}

Universitas Muhammadiyah Cirebon

Email: IndahKY@gmail.com

Citasi: Yulina, I.K. 2017. Back To Nature: Kemajuan Atau Kemunduran. Mangifera Edu Volume 2 Nomor 1. Hal 20-31

\begin{abstract}
ABSTRAK
Seiring dengan perkembangan teknologi, peradaban, dan jumlah penduduk, maka konsumen jamu tradisional mulai berkurang. Masyarakat cenderung untuk memilih obatobatan kimia yang lebih praktis dari jamu tradisional dan khasiatnya yang berlangsung cepat. Penemuan-penemuan obat baru menghasilkan lebih dari 500 macam obat setiap tahunnya. Namun saat ini, kesadaran masyarakat akan back to nature semakin meningkat, dilihat dari penggunaan obat tradisional/obat herbal, baik di negara yang sedang berkembang maupun negara maju cenderung terus meningkat. Obat herbal Indonesia, yang dikenal sebagai jamu, sejak berabad-abad telah digunakan secara luas oleh bangsa Indonesia untuk memelihara kesehatan dan mengobati penyakit. Pengembangan dan penggunaan obat herbal Indonesia ke depannya, harus didasarkan bukti-bukti ilmiah yang kuat, terutama melalui penelitian dan pengembangan, serta terstandarisasi, sehingga dapat diintegrasikan dalam sistem pelayanan kesehatan nasional.
\end{abstract}

Kata Kunci: Back to nature, obat tradisional

\section{PENDAHULUAN}

Keanekaragaman hayati (biodiversity) terbesar kedua di dunia setelah Brazil berada di Indonesia, yang terkenal sebagai mega center dengan tumbuhan tropis dan biota lautnya. Sekitar 30.000 jenis tumbuhan dan 7.000 di antaranya ditengarai memiliki khasiat sebagai obat yang sudah digunakan turun-temurun seperti rempah-rempah (lada, pala, cengkeh) dan pengobatan herbal (kumis kucing, mahoni, mengkudu, saga, asam jawa, cabe jawa, dll). Dengan cara mencoba-coba, secara empiris orang purba mendapatkan pengalaman dengan berbagai macam daun atau akar tumbuhan untuk menyembuhkan penyakit. Pengetahuan ini secara turun temurun disimpan dan dikembangkan, sehingga muncul ilmu pengobatan rakyat, sebagaimana pengobatan tradisional jamu di Indonesia.

Saat ini, kondisi pertanian semakin memprihatinkan karena beberapa faktor, antara lain semakin menyempitnya lahan pertanian sehingga tak mampu lagi memenuhi kebutuhan masyarakat dan berkurangnya minat kaum muda dalam bidang pertanian, 
sehingga muncul usaha-usaha untuk mencapai kemakmuran melalui usaha non pertanian. Kegiatan non pertanian ini dilakukan antara lain dengan pengembangan industri jamu tradisional. Pendapat umum menyebutkan bahwa hubungan manusia dengan obat telah mulai semenjak mereka dilahirkan.

Sejalan dengan laju perkembangan teknologi, peradaban, dan jumlah penduduk, maka konsumen jamu tradisional mulai berkurang karena mereka cenderung untuk memilih obat-obatan kimia yang lebih praktis dari jamu tradisional. Berbeda dengan jamujamu tradisional yang pada awalnya di produksi untuk memenuhi kebutuhan sendiri, dan konsumennya kebanyakan berada di pedesaan. Saat ini semakin langka orang yang dapat meramu jamu dengan aktivitas yang seringkali berbeda-beda tergantung dari asal tanaman dan cara pembuatannya. Karena dianggap kurang memuaskan, maka lambat laun ahli-ahli kimia mulai mencoba mengisolasi zat-zat aktif yang terkandung dalam tanaman- tanaman sehingga menghasilkan serangkaian zat-zat kimia sebagai obat, misalnya efedrin dari tanaman Ephedra vulgaris, atropin dari Atropa belladonna, morfin dari Papaver somniferium, digoksin dari Digitalis lanata, reserpin dari Rauvolfia serpentina, vinblastin dan Vinkristin adalah obat kanker dari Vinca rosea.

Pada permulaan abad XX mulailah dibuat obat-obat sintesis, misalnya asetosal, di susul kemudian dengan sejumlah zat-zat lainnya. Pendobrakan sejati baru tercapai dengan penemuan dan penggunaan obat-obat kemoterapeutik sulfanilamid (1935) dan penisillin (1940). Sejak tahun 1945 ilmu kimia, fisika dan kedokteran berkembang dengan pesat dan hal ini menguntungkan sekali bagi penyelidikan yang sistematis dari obat-obat baru.

Penemuan-penemuan baru menghasilkan lebih dari 500 macam obat setiap tahunnya, sehingga obat-obat kuno semakin terdesak oleh obat-obat baru (Thomford et al, 2015). Kebanyakan obat-obat yang kini digunakan di temukan sekitar 20 tahun yang lalu, sedangkan obat-obat kuno ditinggalkan dan diganti dengan obat modern tersebut.

Menjelang tahun $2000 \mathrm{M}$, istilah "back to nature” menjadi sangat populer, yang diartikan sebagai "beralih ke alam". Pada saat itu, manusia belum dapat memahami apa yang dimaksud dengan kembali ke alam atau kembali kepada yang serba alami ini. Back to nature merupakan slogan, ajakan, atau renungan untuk menjaga alam, tubuh, dan apa saja sebagai makhluk ciptaan Allah SWT. Slogan itu juga mengajak manusia agar memanfaatkan alam secara bijaksana, merawat, memelihara diri dari kerusakan, dan mempertahankan demi kemaslahatan manusia itu sendiri. Begitu maraknya obat-obatan yang mengandung bahan kimia justru menambah deret panjang penyakit. Kampanye back 
to nature membuat orang sadar betapa bahayanya obat-obat yang mengandung bahan kimiawi dan betapa berbahaya efek samping yang ditimbulkan.

Namun permasalahannya di sini adalah apakah dengan kembali ke alam manusia menjadi mengalami kemunduran peradaban? Atau apakah sebaliknya, dengan kembali ke alam manusia sejatinya adalah kembali ke hakekat alam yang sesungguhnya?

\section{HASIL DAN PEMBAHASAN}

\section{Sejarah Perkembangan Jamu di Masyarakat}

Obat pertama yang digunakan adalah obat yang berasal dari tanaman, yang di kenal dengan sebutan obat tradisional (jamu). Istilah jamu muncul pada zaman Jawa Baru (15-16 M) dan berasal dari gabungan dua kata "Djampi” dan "Oesodo”. Djampi adalah bahasa Jawa Kromo Inggil yang berarti penyembuhan menggunakan ramuan obat-obatan dan ajian. Sedangkan "Oesodo" berarti kesehatan. Sedangkan istilah untuk peracik jamu adalah "Acaraki". Dalam masyarakat tradisi, seorang "Acaraki" harus berdoa dan berpuasa dulu sebelum membuat jamu. Jamu tradisional mengalami pasang surut sesuai dengan riak gelombang kebudayaan pada zamannya. Terdapat beberapa era seperti :

1. Zaman Pra-Jepang:

1658 J. Bontius : De Indiae Utriusquere Naturali etMedica

1741G.E.Rumph : Herbarium Amboinense

1748C. Linnaeus : FloraZeylanica

2. Zaman Jepang:

Badan Penghimpun Rumus Jamu (Jawa Izi Hookoo Kai: Ketua dari. A. Rasjid)

3. Zaman BungKarno

1955 - 1965 : Pegobatan Tradisional Shinse dan dukun

4. 1965 - Sekarang:

Prof. Darman, W.H.O. dan sebagainya.

Dalam menyoroti empat fase di atas telah beberapa kali diadakan kongres ataupun pertemuan ilmiah yang menerima laporan-laporan tentang penelitian pengobatan tradisional khususnya yang menggunakan tanaman obat, baik dalam arti indikasi, penggunaan uji klinis atau evaluasi efek samping (Agoes, 1978,1979).

\section{Penemuan Obat Modern}

Penggunaan obat-obatan tradisional diakui sebagai cara untuk belajar tentang obatobatan potensial di masa depan. Seperti diketahui bersama, secara tradisional, sebenarnya 
luka bernanah dapat disembuhkan dengan menutupinya dengan kapang-kapang dari jenis tertentu, tetapi baru sekitar tahun 1928 khasiat ini baru diselidiki secara ilmiah oleh Dr. Alexander Fleming. Dari hasil penelitian Dr. Alexander Fleming, ditemukanlah penisilin. Penilisin adalah sebuah antibiotik yang berguna untuk melawan bakteri dan kuman. Sejak saat itu, beribu-ribu zat sintetis ditemukan (diperkirakan sekitar 500 zat per tahun-nya). Hal ini membuat perkembangan di bidang Farmakoterapi meningkat pesat. Secara umum, kebanyakan obat "kuno" telah ditinggalkan dan diganti obat yang lebih "modern". Selanjutnya adalah persaingan antar sesama obat modern. Pasalnya obat modern dapat terganti dengan obat modern yang lebih baru dan lebih berkhasiat serta lebih efektif. Meski begitu, diperkirakan lebih dari $78 \%$ obat yang beredar sekarang adalah merupakan hasil dari penemuan tiga dasawarsaterakhir.

Food and Drug Administration (FDA), Amerika menjadi badan pengawas obat dan makanan rujukan di hampir seluruh negara di dunia. Oleh karenanya panduan terkait Proses Perkembangan Obat Baru Hingga dipasarkan menjadi wajib diketahui bagi para ahli farmasi diIndonesia.

Perkembangan obat baru hingga dipasarkan harus melalui 5 proses tahapan sebagaiberikut:

Tahap 1 - Penemuan dan perkembangan obat baru

Biasanya, para peneliti menemukan obat baru melalui: wawasan baru ke dalam proses penyakit yang memungkinkan peneliti untuk merancang sebuah produk untuk menghentikan atau membalikkan efek dari penyakit, pengujian berbagai senyawa molekul untuk menemukan efek menguntungkan terhadap sejumlah besar penyakit, perawatan saat ini yang memiliki efek tak terduga, dan teknologi baru, seperti memberikan cara baru untuk menargetkan produk medis untuk target tertentu dalam tubuh atau memanipulasi materigenetik

Pada tahap ini, ribuan senyawa mungkin menjadi kandidat potensial untuk dikembangkan sebagai pengobatan medis. Namun, hanya sejumlah kecil senyawa terlihat menjanjikan dan diteruskan untuk studi lebih lanjut.

Setelah peneliti mengidentifikasi suatu senyawa yang menjanjikan untuk pengembangan, mereka melakukan percobaan untuk mengumpulkan informasi tentang:

- Cara obat diserap, didistribusikan, dimetabolisme, dandiekskresikan

- Manfaat potensi dan mekanismeaksi

- Dosisterbaik 
- Cara terbaik rute pemberian obat (seperti melalui mulut atauinjeksi)

- Efek samping (sering disebut sebagai toksisitas)

Tahap 2 - PengujianPra-klinik

Sebelum pengujian obat kepada manusia, peneliti harus mencari tahu apakah ia memiliki potensi untuk menyebabkan kerusakan serius, yang disebut toksisitas.

Dua jenis penelitian praklinis adalah:

- In Vivo : pengujian dalam mahlukhidup

- In Vitro : pengujian dalam peralatan laboratorium seperti gelas/plastik yang menyerupai kondisi invivo

Biasanya, studi praklinis tidak sangat besar. Namun, penelitian ini harus memberikan informasi rinci tentang tingkat dosis dan toksisitas. Setelah uji praklinis, peneliti meninjau temuan mereka dan memutuskan apakah obat bisa diuji pada manusia.

Tahap 3 - Pengujian Klinik

"Penelitian klinis" mengacu pada penelitian atau uji coba yang dilakukan pada orang. Sebagai pengembang desain studi klinis, mereka akan mempertimbangkan apa yang ingin mereka capai untuk masing-masing fase Clinical Research yang berbeda dan memulai proses Investigational New Drug (IND), sebelum proses ini dilewati maka pengujian klinis tidak bisa dilakukan.

Para peneliti merancang uji klinis untuk menjawab pertanyaan penelitian yang spesifik yang berkaitan dengan produk medis. Percobaan ini mengikuti rencana studi tertentu, yang disebut protokol, yang dikembangkan oleh peneliti atau produsen. Sebelum percobaan klinis dimulai, peneliti meninjau informasi sebelumnya tentang obat untuk mengembangkan pertanyaan penelitian dan tujuannya. Kemudian, mereka memutuskan:

- Sukarelawan yang memenuhi syarat untuk berpartisipasi (kriteriaseleksi)

- Berapa banyak orang akan menjadi bagian daripenelitian

- Berapa lama studi akanberlangsung

- Apakah akan ada kelompok kontrol dan cara lain untuk membatasi Bias penelitian

- Bagaimana obat akan diberikan kepada pasien dan berapadosis

- Penilaian apa yang akan dilakukan, kapan, dan data apa yang akan dikumpulkan

- Bagaimana data akan ditinjau dandianalisis

- Bagaimana berinteraksi dengan obat lain dan selamaperawatan

- Efektivitas suatu obat dibandingkan dengan obat yang sama 
Tahap 4 - PersetujuanFDA

Jika pengembang obat memiliki bukti dari tes awal dan penelitian praklinis dan klinis bahwa obat yang aman dan efektif untuk digunakan, perusahaan dapat mengajukan permohonan untuk memasarkan obat. Tim Review FDA secara menyeluruh memeriksa semua data yang disampaikan pada obat dan membuat keputusan untuk menyetujui atau tidak menyetujuinya. Untuk obat-obatan penyakit langka tertentu memiliki program persetujuandipercepat.

Tahap 5 - Monitoring keamanan obat di pasaran

Meskipun uji klinis memberikan informasi penting tentang efikasi dan keamanan obat, adalah mustahil untuk memiliki informasi yang lengkap tentang keamanan obat pada saat persetujuan. Meskipun langkah-langkah yang ketat dalam proses pengembangan obat, tetap memiliki keterbatasan.

Oleh karena itu, gambaran yang benar dari keamanan produk ini benar-benar berkembang selama bulan dan bahkan bertahun-tahun yang membentuk seumur hidup produk di pasar. Tim peninjau FDA menerima laporan masalah dengan resep dan obat over-the-counter, dan dapat memutuskan untuk menambahkan/ memperingatkan untuk dosis atau penggunaan informasi, serta langkah-langkah lain untuk masalah yang lebih serius.

Penggolongan obat kimia/sintetis dibedakan menjadi 4 golongan, yaitu:

1. Obat Bebas, merupakan obat yang ditandai dengan lingkaran berwarna hijau dengan tepi lingkaran berwarna hitam. Obat bebas umumnya berupa suplemen vitamin dan mineral, obat gosok, beberapa analgetik-antipiretik, dan beberapa antasida. Obat golongan ini dapat dibeli bebas di Apotek, toko obat,toko kelontong,warung.

2. Obat Bebas Terbatas, merupakan obat yang ditandai dengan lingkaran berwarna biru dengan tepi lingkaran berwarna hitam. Obat-obat yang umunya masuk ke dalam golongan ini antara lain obat batuk, obat influenza, obat penghilang rasa sakit dan penurun panas pada saat demam (analgetik- antipiretik), beberapa suplemen vitamin dan mineral, dan obat-obat antiseptika, obat tetes mata untuk iritasi ringan. Obat golongan ini hanya dapat dibeli di Apotek dan toko obatberizin.

3. Obat Keras, merupakan obat yang pada kemasannya ditandai dengan lingkaran yang didalamnya terdapat huruf $\mathrm{K}$ berwarna merah yang menyentuh tepi lingkaran yang berwarna hitam. Obat keras merupakan obat yang hanya bisa didapatkan dengan resep 
dokter atau obat yang masuk kedalam OWA (Obat Wajib Apotek), Obat Wajib Apotek adalah daftar obat obat keras yang dapat diserahkan oleh Apoteker. Obat golongan ini hanya dapat diperoleh diApotek.

4. Obat Narkotika, merupakan zat atau obat yang berasal dari tanaman atau bukan tanaman baik sintesis maupun semi sintesis yang dapat menyebabkan penurunan atau perubahan kesadaran, hilangnya rasa, mengurangi sampai menghilangkan rasa nyeri, dan dapat menimbulkan ketergantungan (UU RI No. 22 Th 1997 tentang Narkotika). Obat ini pada kemasannya ditandai dengan lingkaran yang di dalamnya terdapat palang (+) berwarnamerah.

\section{Perbedaan Obat Sintetis dan Obat Tradisional}

Dalam memutuskan pengobatan dan obat apa yang akan digunakan, tradisional atau kimia, masing-masing harus memikirkan kebutuhan dan situasi serta kondisi yang sedang dihadapi. Salah satu alasannya adalah reaksi dan cara kerja yang berbeda antara kedua jenis obat tersebut. Berikut adalah beberapa fakta dan perbandingan yang harus diingat ketika hendak memutuskan obat jenis apa yang ingin digunakan.

Tabel.1 Perbandingan Obat Tradisional dan Obat Kimia Obat Tradisional Obat Kimia

\begin{tabular}{l|l}
\hline Harganya terjangkau & Harga relatif mahal (impor) \\
\hline $\begin{array}{l}\text { Efek samping relatif kecil bahkan ada } \\
\text { yang sama sekali tidak menimbulkan } \\
\text { efek samping jika digunakan secara } \\
\text { tepat. }\end{array}$ & $\begin{array}{l}\text { Efek samping pengobatan lebih sering } \\
\text { terjadi }\end{array}$ \\
\hline $\begin{array}{l}\text { Reaksinya lambat } \\
\text { Memperbaiki keseluruhan sistem } \\
\text { tubuh }\end{array}$ & $\begin{array}{l}\text { Reaksinya cepat } \\
\text { Hanya memperbaiki beberapa sistem } \\
\text { Tubuh } \\
\text { sulit diatasi dengan obat kimia }\end{array}$ \\
\hline $\begin{array}{l}\text { Terapi sampingan: Diet terhadap } \\
\text { makanan tertentu }\end{array}$ & $\begin{array}{l}\text { Relatif kurang efektif untuk penyakit } \\
\text { Kronis }\end{array}$ \\
\hline & $\begin{array}{l}\text { Terapi sampingan: diet terhadap } \\
\text { makanan tertentu dan perlakuan tertentu } \\
\text { pada tubuh seperti bedah atau operasi } \\
\text { dan manajemen stres. }\end{array}$ \\
\hline
\end{tabular}

Sumber: WHO, 2002

\section{Back to Nature}

Pada tahun 2001, peneliti mengidentifikasi 122 senyawa digunakan dalam pengobatan utama yang berasal dari "ethnomedical" sumber tanaman, 80\% diantaranya telah memiliki penggunaan ethnomedical identik atau terkait dengan penggunaan zat aktif tanaman. Tanaman telah berevolusi kemampuan untuk mensintesis senyawa kimia yang membantu mereka mempertahankan terhadap serangan dari berbagai macam predator 
seperti serangga, jamur dan mamalia herbivora. Secara kebetulan, beberapa senyawa, sementara menjadi racun bagi tanaman predator, ternyata memiliki efek menguntungkan bila digunakan untuk mengobati penyakit manusia.

Metabolit sekunder sangat bervariasi dalam struktur. Sebagian besar tanaman penghasil senyawa metabolit sekunder memanfaatkan senyawa tersebut untuk mempertahankan diri dan berkompetisi dengan makhluk hidup lain di sekitarnya. Tanaman dapat menghasilkan metabolit sekunder (seperti: alkaloid, quinon, tannin, flavonoid, dll.) yang membuat tanaman lain tidak dapat tumbuh di sekitarnya. Berbagai senyawa metabolit sekunder telah digunakan sebagai obat atau model untuk membuat obat baru, contohnya adalah aspirin yang dibuat berdasarkan struktur asam salisilat yang secara alami terdapat pada tumbuhan tertentu.

Sedikitnya 12.000 senyawa telah diisolasi sampai saat ini. Senyawa kimia dalam tanaman menengahi efek mereka pada tubuh manusia dengan cara mengikat molekul reseptor yang ada dalam tubuh, proses tersebut identik dengan yang sudah dipahami dengan baik untuk obat konvensional dan sebagaiobat herbal tersebut tidak berbeda jauh dari obat konvensional dalam hal cara kerjanya. Hal ini menjadikan obat-obatan herbal berprinsip sama efektifnya dengan obat- obatan konvensional dan sejumlah herbal dianggap cenderung menyebabkan efek samping. Selanjutnya, pemalsuan, formulasi yang tidak tepat, atau kurangnya pemahaman tentang interaksi tanaman dan obat menyebabkan efek samping yang kadang-kadang mengancam nyawa ataumematikan.

\section{KESIMPULAN}

Dari hasil analisis dan pembahasan yang telah dipaparkan dapat disimpulkan bahwa Perangkat Pembelajaran Ekosistem dengan Penugasan Presentasi Poster dapat meningkatkan motivasi belajar siswa dan hasil belajar (kognitif) siswa melalui penguasaan konsep mencapai kriteria valid dengan menunjukkan kategori sangat baik.

Penerapan perangkat pembelajaran ekosistem dengan penugasan presentasi poster mencapai kriteria efektif dengan keberhasilan indikator hasil belajar (kognitif) mencapai 86,7\% ketuntasan secara klasikal, aktivitas siswa dalam kategori aktif dan sangat aktif mencapai $86,7 \%$ dari seluruh siswa, dan meningkatnya sikap dan motivasi siswa. 
Penerapan perangkat pembelajaran ekosistem mencapai kriteria praktis dengan keberhasilan indikator respon positif ditunjukkan sebesar $87,1 \%$ siswa memberi respon positif.

Dewasa ini penggunaan obat herbal cenderung terus meningkat, baik di negara sedang berkembang maupun di negara-negara maju. Peningkatan penggunaan obat herbal ini mempunyai dua dimensi penting yaitu aspek medik terkait dengan penggunaannya yang sangat luas diseluruh dunia, dan aspek ekonomi terkait dengan nilai tambah yang mempunyai makna pada perekonomianmasyarakat.

Obat Tradisional Cina/Traditional Chines Medicine (TCM) memiliki akar sejarah yang jauh lebih tua dibanding dengan obat entitas kimia (chemical entity) yang berasal dari Barat (Chang, 1999). TCM telah lebih dari 3.000 tahunmenjadi bagian dari budaya Cina dan telah puluhan abad menyebar luas dibawa oleh oleh warga bangsa itu yang merantau ke seluruh penjuru dunia (Chinese Overseas). Dengan meningkatnya globalisasi dan kemajuan di bidang teknologi informasi dan komunikasi, maka penyebaran TCM makin meluas ke seluruh dunia dan terus meningkat dari tahun ketahun.

Dalam konteks penggunaan obat tradisional/ herbal yang terus meningkat, WHO menggaris bawahi tentang pentingnya suatu kerangka kerja (framework) untuk aksi bersama antara WHO dan negara anggota (country member) (WHO, 2002). Kerangka kerja tersebut bertujuan agar obat tradisional/herbal dapat berperan makin besar dalam mengurangi angka kematian dan kesakitan terutama di kalangan masyarakat yang tidak mampu. Strategi WHO dalam hal obat tradisional mencakup empat tujuan utama yaitu (WHO, 2002) :

1. Mengintegrasikan secara tepat obat tradisional dalam sistem pelayanan kesehatan nasional dengan mengembangkan dan melaksanakan kebijakan nasional obat tradisional dengan berbagaiprogramnya.

2. Meningkatkan keamanan (safety), khasiat dan mutu dengan memperkuat knowledge-base obat tradisional dan regulasi dan standar jaminan mutu (quality assurancestandard).

3. Meningkatkan ketersediaan dan keterjangkauan obat tradisional terutama untuk masyarakat yang tidakmampu.

4. Mempromosikan penggunaan obat tradisional secara tepat oleh tenaga profesional medik maupun olehkonsumen. 
Indonesia sebagai negara anggota, perlu menjabarkan strategi global WHO tersebut dalam suatu kebijakan nasional yang komprehensif dengan program- program yang memiliki arah dan sasaran ke depan yang jelas dengan melibatkan partisipasi aktif seluruh sektor terkait.

\section{Obat Herbal di Indonesia}

Obat herbal Indonesia pada dasarnya dapat dikelompokkan dalam tiga kategori, yaitu : (1) Jamu; (2) Obat Herbal Terstandar; dan (3) Fitofarmaka. Jamu sebagai warisan budaya bangsa perlu terus dikembangkan dan dilestarikan dengan fokus utama pada aspek mutu dan keamanannya (safety). Khasiat jamu sebagai obat herbal selama ini didasarkan pengalaman empiris yang telah berlangsung dalam kurun waktu yang sangat lama.

Berdasarkan berbagai hasil penelitian ilmiah yang telah dilakukan selama ini ternyata sebagian besar jamu yang digunakan oleh masyarakat luas mengandung dua komponen penting, yaitu imunomodulator dan anti oksidan. Dengan demikian jamu bermanfaat untuk menjaga dan memelihara kesehatan, sehingga tidak mudah sakit karena sistem imunitas tubuh terpelihara dan berfungsi dengan baik.

Obat herbal terstandar adalah obat yang simplisianya telah dilakukan standarisasi dan telah dilakukan uji pra klinik. Standarisasi simplisia merupakan upaya menyeluruh dimulai dengan pemilihan lahan (unsur tanah) yang tepat untuk tumbuhan obat tertentu, budi daya yang baik sampai pasca panen (good agriculture practices). Setiap simplisia mengandung komponen yang kompleks.

Untuk standarisasi bagi setiap simplisia maka perlu ditetapkan zat penanda (finger print) yang digunakan sebagai parameter. Fitofarmaka adalah adalah obat herbal yang telah dilakukan uji klinik secara lengkap. Dengan uji klinik yang lengkap dan mengikuti prinsipprinsip uji klinik yang baik, maka fitofarmaka dapat digunakan dalam pelayanan kesehatan formal karena memiliki evidence base dan dukungan data ilmiah yang kuat. Pertumbuhan pasar obat herbal Indonesia selama 5 tahun terakhir rata-rata sekitar 15\% dan sebagaian besar masih dipasarkan di dalam negeri. Selanjutnya perlu ada perencanaan dan upayaupaya yang lebih sistematis untuk pengembangan pasar ekspor terutama pasarASEAN.

\section{SIMPULAN}

Back to nature merupakan usaha yang dilakukan manusia untuk kembali ke alam, salah satunya adalah melalui obat herbal. Obat herbal di Indonesia termasuk Jamu perlu 
terus dikembangkan dengan penelitian yang memiliki basis ilmiah yang kuat sehingga dapat diintegrasikan secara tepat dalam sistem pelayanan kesehatan nasional. Budi daya tumbuhan obat Indonesia penting untuk dilakukan selain untuk menjaga kelestariannya, juga untuk meningkatkan kualitas obat herbal Indonesia dengan nilai tambah ekonomi yang lebih besar. Standarisasi simplisia dan obat herbal Indonesia serta jaminan atas mutu, kemanan dan kemanfaatannya merupakan aspek strategis dalam prespektif medik maupun ekonomi.

\section{DAFTAR PUSTAKA}

Ball. A. 2012. American Educational Reseach Associations 2012 Anual Meeting Call for Submissions. Journal vancouver brithis columbia-canada . Vol 13. No. 2.

Calixto, J.B. 2000. Efficacy, safety, quality control, marketing and regulatory guidelines for herbal medicines (phytotherapeutic agents). Braz. J. med. biol. Res., 33, 179-189

Chandra. 2007. 'Pembelajaran Sains Menurut Pandangan Kontruktivisme'. Jurnal Pendidikan Serambi Ilmu, 6(1): 19-24.

Chang, Joseph. 1999. Scientific Evaluation of Traditional Chinese Medicine Under DSHEA (The Dietary Supplement Health and Education Act): A Conundrum. The Journal of Alternative and Complementary Medicine Volume 5, Number 2 pp181-189

Ernst, Edzard. 2004. Prescribing Herbal Medications Appropriately. Journal of Family Practice. Vol. 53. No. 12 nn. Some Traditional Herbal Medicines. Iarc Monographs Volume 82

Goldman. K. \& Schalmaz. K. 2010. Poster Seasons Fundamentals Becoming a Proficient "Poster Child" for Health Education.. Journal health ptomotion practice. Vol 11. No. 3.

M. 2013. Compilation of a herbal medicine formulary for herbal substances in Malta and its usefulness amongst healthcare professionals. Journal of Young Pharmacists 5, 22-25

Samsudi, 2009. Disain Penelitian Pendidikan. Semarang: Universitas Negeri Semarang Press.

Sanjaya, W. 2009. Strategi Pembelajaran Berorientasi Standar Proses Pendidikan. Jakarta: Kencana.

Sukestiyarno, 2010. Olahdata Penelitian Berbantuan SPSS. Semarang: Universitas Negeri Semarang.

Spiteri, Maria; Attard, Everaldo; Serracino-Inglott, Anthony; Azzopardi, Lilian 
Thomford, Nicholas E.; Dzobo, Kevin; Chopera, Denis; Wonkam, Ambroise; Skelton, Michelle; Blackhurst, Dee; Chirikure, Shadreck; Dandara, Collet. 2015. Pharmacogenomics Implications of Using Herbal Medicinal Plants on African Populations in Health Transition. Pharmaceuticals 8,637-663

WHO. 2002. Traditional Medicine - Growing Needs and Potential. Geneva 